\title{
PODMIOTY PRZESTEPSTW KORUPCYJNYCH W ŚWIETLE DOKUMENTÓW MIĘDZYNARODOWYCH I AKTÓW PRAWA POLSKIEGO
}

\section{Uwagi wstępne}

Korupcja jest jedną z poważnych przeszkód rozwoju gospodarczego i społecznego, ponieważ zniekształca funkcjonowanie rynków, osłabia pozytywny wpływ zagranicznych inwestycji i spowalnia wzrost ekonomiczny ${ }^{1}$. Korupcja stanowi szczególnie poważne zagrożenie w państwach rozwijających się, zakłócając funkcjonowanie instytucji publicznych, podważając niezależność wymiaru sprawiedliwości, powodując izolację międzynarodowa, zwiększając polityczną niestabilność ${ }^{2}$ i wzmacniając organizacje przestępcze ${ }^{3}$. Wysoki poziom korupcji uniemożliwia państwom wypełnianie ich obowiązków w zakresie poszanowania i ochrony praw człowieka ${ }^{4}$, dlatego niektórzy przedstawiciele nauki klasyfikują korupcję jako przestępstwo przeciwko ludzkości ${ }^{5}$. Polityka kryminalna, by była

${ }^{*}$ Dr, adwokat, Kancelaria Adwokacka w Warszawie; e-mail: dabrowski17@wp.pl.

${ }^{1}$ M.K. Hurst, Eliminating Bribery in International Business Transactions, "Journal of International Law and Practice" 1997, nr 6, s. 114.

${ }^{2}$ H.-E. Sung, Between demand and supply: Bribery in international trade, "Crime, Law \& Social Change" 2005, nr 44, s. 113.

${ }^{3}$ D. Metcalfe, The OECD Agreement to Criminalize Bribery: A Negotiation Analytic Perspective, "International Negotiation” 2000, nr 5, s. 131.

${ }^{4}$ Zob. International Council on Human Rights Policy, Corruption and Human Rights: Making the Connection, Versoix 2009, Switzerland, www.archive.transparency.org/publications/other/ichrp_ti_report [dostęp: 13.06.2015 r.].

${ }^{5}$ J.T. Gathii, Defining the Relationship Between Human Rights and Corruption, „University of Pennsylvania Journal of International Law" 2009, nr 31, s. 147; I. Bantekas, Corruption as an International Crime and Crime Against Humanity, "Journal of International Justice" 2006, 
$\mathrm{w}$ pełni wartościowym i skutecznym instrumentem $\mathrm{w}$ walce $\mathrm{z}$ przestępczością korupcyjną, powinna uwzględniać jej międzynarodowe aspekty. Działania podejmowane wyłącznie w wewnątrzpaństwowych systemach prawnych nie są dziś wystarczające, co sprawia, że współpraca międzynarodowa w zapobieganiu i zwalczaniu korupcji jest niezbędna. W walkę z korupcją są zaangażowane organizacje międzynarodowe działające na płaszczyźnie powszechnej i regionalnej. Opracowują one liczne antykorupcyjne dokumenty o różnej mocy prawnej, których celem jest zwalczanie i zapobieganie korupcji. Konwencja amerykańska przeciw korupcji ${ }^{6}$, Konwencja afrykańska o zapobieganiu i zwalczaniu korupcji ${ }^{7}$, Protokół Wspólnoty Gospodarczej Państw Afryki Zachodniej przeciw korupcji ${ }^{8}$, Protokół Południowoafrykańskiej Wspólnoty Rozwoju przeciw korupcji ${ }^{9}$, Konwencja karnoprawna o korupcji Rady Europy ${ }^{10}$ wraz z Protokołem dodatkowym ${ }^{11}$, Konwencja ONZ przeciw korupcji ${ }^{12}$, Konwencja OECD o zwalczaniu przekupstwa zagranicznych funkcjonariuszy publicznych w międzynarodowych transakcjach handlowych ${ }^{13}$, Konwencja w sprawie zwalczania korupcji funkcjonariuszy Wspólnot Europejskich lub funkcjo-

nr 4, s. 473; odmiennie M. Balcerzak, Korupcja jako zagrożenie dla społeczności międzynarodowej i praw człowieka, [w:] J. Symonides (red.), Świat wobec wspólczesnych wyzwań i zagrożeń, Warszawa 2010, s. 539.

${ }^{6}$ Organization of American States, Inter-American Convention against Corruption, Caracas, 29 III 1996, www.oas.org [dostęp: 13.06.2015 r.], (dalej: Konwencja amerykańska).

7 African Union, Convention on Preventing and Combating Corruption, Maputo, Mozambik 11 VII 2003, www.african-union.org [dostęp: 13.06.2015 r.], (dalej: Konwencja afrykańska).

${ }^{8}$ Economic Community of West African States (ECOWAS), Protocol on the Fight Against Corruption, 21 XII 2001, www.ecowas.int [dostęp: 13.06.2015 r.], (dalej: Protokół ECOWAS).

9 Southern African Development Community (SADC), Protocol against Corruption, Blantyre, Malawi, 14 VIII 2001, www.sadc.int [dostęp: 13.06.2015 r.], (dalej: Protokól SADC).

10 Criminal Law Convention on Corruption, Strasbourg, 27 I 1999, European Treaty Series No 173, www.coe.int [dostęp: 13.06.2015 r.], (dalej: Konwencja karnoprawna).

11 Protokół Dodatkowy do Konwencji karnoprawnej o korupcji Rady Europy, Strasburg, 15 maja 2003 r., Council of Europe Treaty Series No. 191, www.conventions.coe.int/ Treaty/en/Treaties /Html/191.htm [dostęp: 13.06.2015 r.], (dalej: Protokół dodatkowy).

${ }^{12}$ United Nations, Convention against Corruption, New York, 31 X 2003, www.un.org [dostęp: 13.06.2015 r.], (dalej: Konwencja ONZ).

${ }^{13}$ Konwencja OECD o zwalczaniu przekupstwa zagranicznych funkcjonariuszy publicznych w międzynarodowych transakcjach handlowych, Paryż, 21 listopada 1997 r. (Dz. U. z 2001 r. Nr 23, poz. 264), (dalej: Konwencja OECD). 
nariuszy państw członkowskich Unii Europejskiej ${ }^{14}$ oraz Decyzja ramowa

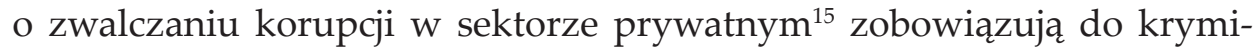
nalizacji zachowań korupcyjnych w nich określonych. Odpowiedzialności karnej podlegają jedynie ściśle określone podmioty zaangażowane w działalność korupcyjną.

Głównym zamierzeniem opracowania było określenie kręgu podmiotów zdolnych do ponoszenia odpowiedzialności karnej za przestępstwa korupcyjne jakie występują w dokumentach międzynarodowych i uregulowaniach prawa polskiego. W opracowaniu poddano analizie dokumenty odnoszące się do zjawiska korupcji w sposób kompleksowy, przyjmowane pod auspicjami międzynarodowych organizacji rządowych o charakterze powszechnym i regionalnym oraz przepisy prawa krajowego. Główny nacisk położono na określenie zakresu znaczeniowego poszczególnych kategorii podmiotów krajowych w sektorze publicznym, tj.: „funkcjonariusza publicznego" oraz „osoby pełniącej funkcję publiczną”, jak również „podmiotów zagranicznych" funkcjonujących w wymiarze międzynarodowym; całość dopełnia określenie podmiotów sektora prywatnego.

\section{Krajowy funkcjonariusz publiczny jako podmiot przestępstw korupcyjnych}

Sprawa zakwalifikowania danej osoby jako funkcjonariusza publicznego łączy się z możliwością stania się podmiotem przestępstw osób pełniących funkcję publiczną. Analizowane dokumenty definiują pojęcie funkcjonariusza publicznego posługując się różnymi metodami. Po pierwsze odsyłają do definicji pojęcia funkcjonariusza publicznego obowiązującego w prawie wewnętrznym państwa strony, tak Konwencja karnoprawna i unijna. Po drugie posługują się własną, autonomiczną definicją tak Konwencja afrykańska, amerykańska, Protokół ECOWAS oraz SADC. Po trzecie można wyróżnić metodę mieszana, którą zastosowano w Konwencji

${ }^{14}$ Konwencja sporządzona na podstawie artykułu K.3 ustęp 2 litera c) Traktatu o Unii Europejskiej w sprawie zwalczania korupcji urzędników Wspólnot Europejskich i urzędników państw członkowskich Unii Europejskiej, 26 maja 1997 r. (Dz. Urz. UE C 195 z 25 czerwca 1997 r.), (dalej: Konwencja unijna).

15 Decyzja ramowa Rady 2003/568/WSISW w sprawie zwalczania korupcji w sektorze prywatnym, 22 lipca 2003 r. (Dz. Urz. UE L 192 z 31 lipca 2003 r.), (dalej: Decyzja ramowa). 
ONZ i Protokole dodatkowym. Zaznaczyć należy, że nie są to definicje w ścisłym tego słowa znaczeniu, gdyż stworzenie jakiejś ogólnej formuły było niemożliwe.

\subsection{Definicje odsyłające}

Zgodnie z art. 1 pkt a Konwencji karnoprawnej pojęcie „funkcjonariusza publicznego" należy, w szczególności, rozumieć przez odniesienie do definicji ,funkcjonariusza”, , urzędnika publicznego", ,burmistrza”, , ministra” lub „sędziego" w prawie wewnętrznym państwa, w którym dana osoba wykonuje tę funkcję na użytek prawa karnego. Definicją objęto wszystkie kategorie funkcjonariuszy publicznych, by uniknąć luk prawnych w kryminalizacji łapownictwa w sektorze publicznym.

Swoistą podkategorię w tej definicji, pod względem sposobu ujmowania, tworzą te osoby, które są wyraźnie w niej określone, tj. burmistrz, minister, sędzia (prokurator).

Sprecyzowany w art. 1 pkt b termin „sędzia” obejmuje, poza samymi sędziami, prokuratorów, mimo że w niektórych państwach nie są zaliczani do części sądownictwa, oraz osoby sprawujące urzędy sądownicze. W przypadku osób wykonujących funkcje sędziowskie decydującym elementem jest pełniona funkcja (która ze swej natury powinna mieć charakter sądowniczy), a nie oficjalna nazwa danego typu stanowiska. Nie ma przy tym znaczenia, czy osoby te zostały wybrane czy mianowane ${ }^{16}$. Definicja ta została przyjęta wyłącznie dla celów Konwencji i od jej stron zależy, czy uznać sędziów i prokuratorów za funkcjonariuszy publicznych ${ }^{17}$.

Definicja funkcjonariusza publicznego w Konwencji karnoprawnej powinna zawierać również termin „burmistrza” i „ministra”. W wielu państwach osoby te w ponoszeniu odpowiedzialności karnej są zrównane z funkcjonariuszami publicznymi. Jednak, by uniknąć ewentualnych luk prawnych dających możliwość wyjścia poza zakres uregulowań konwencyjnych osobom pełniącym ważne funkcje, uznano za konieczne umieszczenie ich $w$ tej definicji ${ }^{18}$.

${ }^{16}$ Explanatory Report to the Criminal Law Convention on Corruption, European Treaty Series No. 173, www.coe.int [dostęp: 13.06.2015 r.], pkt 29.

${ }_{17}$ Explanatory Report on the Criminal, pkt 29.

18 Explanatory Report on the Criminal, pkt 28. 
W art. 4 Konwencji karnoprawnej rozszerzono krąg podmiotów narażonych na czyny korupcyjne o członków krajowych zgromadzeń przedstawicielskich. Zgodnie z raportem wyjaśniającym, dotyczy to członków krajowych zgromadzeń przedstawicielskich szczebla lokalnego, regionalnego i krajowego, wybranych lub mianowanych ${ }^{19}$, jednak Strony Konwencji mogą przyjąć swą własną definicję. Kategoria tych osób powinna zasadniczo dotyczyć członków parlamentu (jeśli to możliwe, obu izb), członków lokalnych i regionalnych zgromadzeń oraz członków każdej innej publicznej jednostki, którzy zostali wybrani lub mianowani, oraz którzy "sprawują władzę ustawodawczą lub administracyjną" (art. 4 in fine). Pojęcie to, w niektórych państwach, obejmuje również burmistrzów jako członków rad lokalnych oraz ministrów jako członków parlamentu. Wyrażenie „władza administracyjna" ma na celu objęcie postanowieniami członków zgromadzeń publicznych, którzy nie mają władzy ustawodawczej, jak w przypadku regionalnych zgromadzeń lub lokalnych rad. Mogą jednak mieć znaczny wpływ w obszarze regulacyjnym, planowania, udzielania koncesji lub pozwoleń.

Z kolei Konwencja unijna posługuje się pojęciem „urzędnik”. Zgodnie $\mathrm{z}$ definicją zawartą $\mathrm{w}$ art. 1 pkt a, termin ten oznacza dowolnego urzędnika szczebla wspólnotowego lub krajowego, także urzędnika krajowego każdego innego państwa członkowskiego. Taka definicja wymagała sprecyzowania dodatkowo dwóch pojęć: urzędnika wspólnotowego i urzędnika krajowego.

Przy definiowaniu pojęcia „urzędnik krajowy” posłużono się metodą definiowania "funkcjonariusza publicznego" z Konwencji karnoprawnej, przez odesłanie do definicji „urzędnika” lub „urzędnika publicznego” występującej w prawie krajowym państwa członkowskiego, w którym dana osoba sprawuje taką funkcję, na użytek prawa karnego.

Zgodnie z omawianymi konwencjami w przypadku postępowania dotyczącego funkcjonariusza publicznego innego państwa, państwo ścigające może stosować definicję funkcjonariusza publicznego tylko w zakresie zgodnym z jego prawem krajowym ${ }^{20}$, należy zatem brać pod uwagę szczególne sytuacje w innych państwach dotyczące statusu osób sprawujących funkcje publiczne ${ }^{21}$. Oznacza to, że definicja przyjęta $\mathrm{w}$ prawie innego

19 Explanatory Report on the Criminal, pkt 44, 45.

${ }^{20}$ Art. 1 pkt c Konwencji karnoprawnej; art. 1 pkt c Konwencji unijnej.

${ }^{21}$ C. Nowak, Dostosowanie prawa polskiego do instrumentów międzynarodowych dotyczacych korupcji, Raport Fundacji im. S. Batorego, Warszawa 2004, s. 10. 
państwa nie jest rozstrzygająca kiedy osoba, której sprawa dotyczy nie ma statusu funkcjonariusza publicznego w prawie państwa ścigającego ${ }^{22}$.

Na gruncie prawa polskiego eksplikację zwrotu „funkcjonariusz publiczny" zawiera art. $115 \S 13$ ustawy z dnia 6 czerwca 1997 r. - Kodeks karny ${ }^{23}$. Przepis zawiera enumeratywne wyliczenie osób będących funkcjonariuszami publicznymi. Nie budzi wątpliwości włączenie do zakresu pojęcia "funkcjonariusz publiczny" takich podmiotów, jak Prezydent RP, poseł do Sejmu lub Parlamentu Europejskiego, senator, radny, sędzia, ławnik, prokurator, notariusz ${ }^{24}$, komornik ${ }^{25}$ i kurator sądowy. Nie występują zatem trudności związane z ustaleniem, czy określona osoba posiada przymiot któregokolwiek z wymienionych wyżej podmiotów, bowiem ich nazwy mają ściśle oznaczony zakres desygnatów ${ }^{26}$.

Jednak $\mathrm{w}$ przypadku niektórych funkcji związanych $\mathrm{z}$ wymiarem sprawiedliwości ich sprawowanie poprzedzone jest okresem szczególnego, zazwyczaj trwającego kilka lat przygotowania (stażu) zawodowego, zwanego asesurą. W tym kontekście pojawia się kwestia, czy asesorzy, a więc osoby nieposiadające jeszcze nominacji czyniącej z nich podmioty wskazane w komentowanym przepisie, mogą zostać zaliczone do kręgu funkcjonariuszy publicznych. W doktrynie przedmiotu i orzecznictwie Sądu Najwyższego brak szczegółowych wypowiedzi dotyczących statusu asesorów. Odnośnie do asesora komorniczego stwierdza się, że co prawda nie jest on funkcjonariuszem publicznym w rozumieniu przepisów Kodeksu karnego ${ }^{27}$, jednak ma on taki status, gdy pełni zlecone mu obowiązki zastępcy komornika na podstawie art. 26 ustawy z dnia 29 sierpnia 1997 r. o komornikach sądowych i egzekucji ${ }^{28}$ lub prowadzi czynności egzekucyjne zlecone mu przez komornika w trybie art. 33 tej ustawy. Od-

22 Explanatory Report on the Criminal, pkt 30.

${ }^{23}$ Ustawa z dnia 6 czerwca 1997 r. - Kodeks karny (Dz. U. Nr 88, poz. 553 z późn. zm.), (dalej: k.k.).

${ }^{24}$ Szerzej zob. J. Bodio, Status prawny notariusza - wybrane zagadnienia, „Rejent” 2011, nr 10, s. 9 .

${ }^{25}$ Szerzej zob. A. Barańska, Status prawny komornika sądowego i mienia kancelarii komorniczej, „Przegląd Prawa Egzekucyjnego” 2008, nr 1-2, s. 15 i n.

${ }^{26}$ J. Giezek, Komentarz do art. 115 Kodeksu karnego, [w:] J. Giezek (red.), N. Kłączyńska, G. Łabuda, Kodeks karny. Część ogólna. Komentarz, Warszawa 2012, s. 740.

${ }^{27}$ Uchwała Sądu Najwyższego z 30 kwietnia 2003 r., I KZP 12/03, „,Orzecznictwo Sądu Najwyższego Izba Karna i Wojskowa" 2003, z. 5-6, poz. 42.

${ }_{28}$ Ustawa z dnia 29 sierpnia 1997 r. o komornikach sądowych i egzekucji (tekst jedn. Dz. U. z 2011 r. Nr 231, poz. 1376 z późn. zm.). Odmiennie zob. M. Jonderko, Kilka uwag na temat statusu prawnego asesora komorniczego, „Przegląd Prawa Egzekucyjnego” 2009, nr 4-5, 
nośnie do asesora notarialnego stwierdza się, że niezależnie od ewentualnej realizacji znamion strony przedmiotowej oraz podmiotowej popełnienie tego przestępstwa przez asesora nie jest możliwe ${ }^{29}$. Wskazać należy, że w katalogu podmiotów będących funkcjonariuszami publicznymi nie uwzględniono ",asesora” - instytucje tę przewiduje ustawodawstwo, lecz osoby pełniące obowiązki asesora nie mogą być utożsamiane z prokuratorem, notariuszem lub komornikiem. Odmienna interpretacja oznaczałaby poddanie odpowiedzialności karnej wskazanych osób, mimo że Kodeks karny wyraźnie i jednoznacznie odnosi się jedynie do osób, które w sensie formalnym uzyskały status prokuratora, notariusza lub komornika ${ }^{30}$.

Zgodnie z Kodeksem karnym funkcjonariuszami publicznymi są także funkcjonariusze finansowych organów postępowania przygotowawczego lub organów nadrzędnych nad tymi organami, którymi są w szczególności funkcjonariusze urzędów skarbowych oraz urzędów celnych, inspektorzy kontroli skarbowej, a także funkcjonariusze izb skarbowych oraz izb celnych.

W katalogu osób posiadających status funkcjonariusza publicznego znalazły się również podmioty uczestniczące w postępowaniu upadłościowym. Do podmiotów tych należy syndyk ${ }^{31}$, nadzorca sądowy oraz zarządca, których uznaje się za funkcjonariuszy publicznych $\mathrm{z}$ chwilą powołania $\mathrm{w}$ jednej $\mathrm{z}$ trzech wymienionych ról $\mathrm{w}$ ramach konkretnego postępowania upadłościowego ${ }^{32}$.

Kolejną grupą osób zaliczanych w prawie polskim do funkcjonariuszy publicznych są osoby będące pracownikami administracji rządowej, innego organu państwowego (np. administracja Sejmu czy Senatu) lub samorządu terytorialnego. Do grona funkcjonariuszy publicznych zaliczono również osoby będące pracownikami organu kontroli państwowej lub organu kontroli samorządu terytorialnego (np. Najwyższa Izba Kontroli, Inspekcja Handlowa, Państwowa Inspekcja Sanitarna, Państwowa Inspekcja Pracy, regionalne izby obrachunkowe) $)^{33}$.

s. 101 i n.; J. Wyrembak, Glosa do uchwaty Sadu Najwyższego z dnia 30 kwietnia 2003 r., IKZP 12/13, „Państwo i Prawo” 2006, nr 11, s. 114 i n.

${ }_{29}^{2}$ J. Giezek, Odpowiedzialność karna notariusza w świetle art. 231 kodeksu karnego, „Rejent" 2006, nr 3, s. 9.

${ }^{30}$ C.P. Kłak, Notariusz a przestępstwo nadużycia władzy publicznej (art. 231 k.k.). Zagadnienia materialnoprawne i procesowe, „Rejent” 2011, nr 2, s. 73.

${ }^{31}$ Ustawa z dnia 15 czerwca 2007 r. o licencji syndyka (Dz. U. Nr 123, poz. 850 z późn. $\mathrm{zm}$.).

32 J. Giezek, Komentarz do art. 115, s. 743.

33 M. Mozgawa (red.), Kodeks karny. Praktyczny komentarz, Warszawa 2007, s. 235. 
Pracownik wymienionych wyżej organów nie jest traktowany jako funkcjonariusz publiczny, jeżeli pełni wyłącznie czynności usługowe. Wśród osób wykonujących takie czynności wymienia się np. kierowców, gońców, sekretarki, sprzątaczki, portierów, pracowników zaopatrzenia i obsługi technicznej ${ }^{34}$.

Funkcjonariuszami publicznymi są także osoby zajmujące kierownicze stanowiska w innych instytucjach państwowych. Instytucjami tymi są państwowe szkoły wyższe i publiczne zakłady opieki zdrowotnej. W piśmiennictwie dąży się do określenia zakresu pojęcia instytucji państwowej albo zawężająco - ograniczając go do jednostek państwowych, których zadaniem jest podejmowanie decyzji władczych ${ }^{35}$, albo rozszerzająco obejmując nim wszystkie państwowe jednostki organizacyjne, powołane do realizacji konstytucyjnych obowiązków państwa wobec obywateli oraz innych zadań publicznych ${ }^{36}$. Pojęcie innej instytucji państwowej, z uwagi na wykładnię językowa, nie obejmuje instytucji samorządowych ${ }^{37}$. Osoby zajmujące kierownicze stanowiska we wskazanych instytucjach to zarówno osoby stojące na ich czele (np. rektorzy szkół wyższych), jak również osoby kierujące wyodrębnionymi częściami tych instytucji (np. dziekani wydziałów i dyrektorzy instytutów w szkołach wyższych).

Do grona funkcjonariuszy publicznych prawo krajowe zalicza też funkcjonariuszy organów powołanych do ochrony bezpieczeństwa publicznego, tj.: policjantów, funkcjonariuszy Agencji Bezpieczeństwa Wewnętrznego, a także funkcjonariuszy innych organów, których zadaniem jest ochrona bezpieczeństwa publicznego, jak strażnik gminny (miejski). Pracownik ochrony wykonujący zadania ochrony w ramach wewnętrznej służby ochrony powołanej przez kierownika jednostki w obiekcie podlegającym obowiązkowej ochronie nie jest zaliczany do funkcjonariuszy publicznych $^{38}$.

Ostatnią grupą osób zaliczanych przez prawo krajowe do funkcjonariuszy publicznych są osoby będące pracownikami międzynarodowego trybunału karnego, chyba że pełnią wyłącznie czynności usługowe. W dok-

${ }^{34}$ M. Mozgawa (red.), Kodeks karny, s. 235.

35 O. Górniok, Z problematyki prawnokarnej prania pieniędzy na tle ustawy z dnia 16 listopada 2000 r., „Przegląd Sądowy” 2002, nr 4, s. 12.

36 A. Zoll (red.), Kodeks karny. Czesść ogólna. Komentarz, t. I, Kraków 2004, s. 1457-1458.

37 Tamże, s. 1458; M. Mozgawa (red.), Kodeks karny, s. 236.

${ }^{38}$ G. Gozdór, Status prawno-karny pracownika ochrony, „Prokuratura i Prawo” 2001, nr 3, s. 143 i n. 
trynie podkreśla się, że zakres terminu „międzynarodowy trybunał karny” obejmuje zarówno trybunały stałe (jak Międzynarodowy Trybunał Karny z siedzibą w Hadze), jak i trybunały ustanawiane ad hoc do rozpoznania określonej sprawy lub kategorii spraw. Kwalifikacja instytucji jako międzynarodowego trybunału karnego nie zależy od tego, jaką nazwę nadano tej instytucji, lecz od tego, czy jest to instytucja prawa międzynarodowego powołana do sprawowania wymiaru sprawiedliwości w sprawach karnych ${ }^{39}$.

W przytoczonym katalogu osób zaliczanych do funkcjonariuszy publicznych brak zawodu lekarza lub lekarza dentysty. Oznacza to, że aby zostać uznanym za funkcjonariusza publicznego dany lekarz musiałby łączyć wykonywanie zawodu lekarza z pełnieniem innej funkcji, funkcji administracyjnej ${ }^{40}$, np. w związku z pełnieniem funkcji kierowniczej, jak dyrektora szpitala, kierownika kliniki, kierownika ośrodka zdrowia, ordynatora oddziału ${ }^{41}$ - zarówno w związku z administrowaniem, jak i udzielaniem świadczeń zdrowotnych ${ }^{42}$, w publicznym zakładzie opieki zdrowotnej, który działa w formie państwowej jednostki budżetowej ${ }^{43}$. Osoby zajmujące kierownicze stanowiska w takich publicznych zakładach opieki zdrowotnej są funkcjonariuszami publicznymi ${ }^{44}$.

\subsection{Definicje autonomiczne}

Wyjaśnienie pojęcia "funkcjonariusz publiczny” w definicjach autonomicznych polega na podaniu desygnatów tej nazwy i, podobnie jak

${ }^{39}$ M. Budyn-Kulik, P. Kozłowska-Kalisz, M. Kulik, M. Mozgawa, Komentarz do art. 115 Kodeksu karnego, [w:] M. Mozgawa (red.), M. Budyn-Kulik, P. Kozłowska-Kalisz, M. Kulik, Kodeks karny. Komentarz, Lex nr 471719.

${ }^{40}$ M. Banasiewicz, R. Kokot, Z problematyki odpowiedzialności karnej za błąd w sztuce lekarskiej, „Nowa Kodyfikacja Prawa Karnego” 2009, nr 24, s. 101; wyrok Sądu Najwyższego z 27 listopada 2000 r., WKN 27/00, „Orzecznictwo Sądu Najwyższego Izba Karna i Wojskowa" 2001, nr 3-4, poz. 21.

${ }^{41}$ M. Surkont, Warunki odpowiedzialności lekarza za łapownictwo bierne, „Przegląd Sądowy" 2000, nr 11-12, s. 29 i n.

${ }^{42}$ Uchwała składu 7 sędziów Sądu Najwyższego z 20 czerwca 2001 r., I KZP 5/01, „Orzecznictwo Sądu Najwyższego Izba Karna i Wojskowa” 2001, nr 9-10, poz. 71.

${ }^{43}$ Ordynator oddziału w publicznym zakładzie opieki zdrowotnej, utworzonym przez organ samorządu terytorialnego, nie jest funkcjonariuszem publicznym, ale może być uznany za osobę pełniącą funkcję publiczną (za: J. Kulesza, Glosa do uchwały Sądu Najwyższego z dnia 20 czerwca 2001, IKZP 5/01, „Prokuratura i Prawo” 2002, nr 10, s. 103 i n.).

${ }^{44} \mathrm{~J}$. Garus-Ryba, Problem odpowiedzialności karnej lekarza za przestępstwo łapownictwa biernego, „Palestra” 2001, nr 7-8, s. 18 in. 
w przypadku Konwencji karnoprawnej, ma charakter definicji regulującej, wiążącej w ramach przepisów karnych.

Zarówno w Konwencji afrykańskiej (art. 1), jak i Konwencji amerykańskiej (art. I) funkcjonariusz publiczny definiowany jest $\mathrm{w}$ taki sam sposób i oznacza jakiegokolwiek urzędnika lub pracownika państwa lub jego agencji, wybranego lub mianowanego w celu wykonywania czynności lub funkcji w imieniu państwa lub w służbie państwu, bez względu na szczebel zajmowany w hierarchii zawodowej ${ }^{45}$. Konwencje te definiują pojęcie funkcjonariusza publicznego posługując się terminem "urzędnik" lub „pracownik”. Ponadto Konwencja amerykańska określając sprawcę przestępstwa sprzedajności używa pojęć „urzędnik rządowy”, „funkcjonariusz publiczny", "urzędnik publiczny”, które należy traktować jako synonimy.

W ustawodawstwie i orzecznictwie Stanów Zjednoczonych termin „funkcjonariusz publiczny" rozumiany jest szeroko i obejmuje nie tylko członków Kongresu, komisarzy, funkcjonariuszy, pracowników lub osoby działające w imieniu Stanów Zjednoczonych, funkcjonariuszy i pracowników egzekutywy, legislatywy i sądownictwa, ale także sędziów przysięgłych i inne osoby działające $w$ imieniu rządu ${ }^{46}$. Terminem tym objęto również świadków, którzy są osobami zeznającymi w procesach sądowych, przesłuchaniach i innych postępowaniach. Dotyczy to przesłuchania przed wszystkimi sądami, komisjami Kongresu, agencjami, komisjami, a także przed funkcjonariuszami uprawnionymi przez prawo Stanów Zjednoczonych do odbioru zeznań i przeprowadzania przesłuchań $^{47}$.

$\mathrm{Z}$ kolei zgodnie $\mathrm{z}$ art. 1 Protokołu SADC funkcjonariusz publiczny jest to jakakolwiek osoba będąca pracownikiem państwa, jego agencji, władz lokalnych lub organizacji para-państwowych oraz osoba zajmująca stanowisko ustawodawcze, wykonawcze lub sądownicze w państwie lub pełniąca funkcję publiczną lub obowiązki w jego agencji lub przedsiębiorstwie. Zgodnie zaś z art. 1 Protokołu ECOWAS funkcjonariusz publicz-

${ }^{45}$ Stany Zjednoczone złożyły deklarację do Konwencji amerykańskiej, zgodnie z którą sformułowanie „na każdym poziomie hierarchii” odnosi się do federalnej struktury Stanów Zjednoczonych; konwencja nie nakłada obowiązków w odniesieniu do postępowania funkcjonariuszy innych niż funkcjonariusze federalni.

${ }^{46}$ C.K. Hamilton, Bribery of Public Officials, "American Criminal Law Review” 1993, nr 30, s. 474.

47 S.E. Lapidus, M. Mogilevich, Public Corruption, "American Criminal Law Review” 2010, nr 47, s. 921. 
ny jest to każda osoba wybrana, powołana, mianowana, która wykonuje funkcje publiczne na zasadach stałych lub tymczasowych.

\subsection{Definicje mieszane}

W Konwencji ONZ eksplikację zwrotu „funkcjonariusz publiczny” zawiera art. 2 pkt a. Po pierwsze, Konwencja posługuje się definicją autonomiczna, zgodnie z którą funkcjonariusz publiczny oznacza każdą osobę pełniącą obowiązki ustawodawcze, wykonawcze, administracyjne lub sądowe w państwie stronie, na jakimkolwiek szczeblu, zarówno z powołania, jak i wyboru, zarówno na zasadach stałych, jak i tymczasowych, zarówno za wynagrodzeniem, jak i bez wynagrodzenia. Odnosi się zatem do rodzaju zajmowanego stanowiska. Termin "obowiązki wykonawcze" obejmuje również sektor wojskowy. Termin na "jakimkolwiek szczeblu” oznacza obowiązki służbowe pełnione na wszystkich poziomach i w jednostkach od narodowych do lokalnych ${ }^{48}$. Po drugie, pojęcie to oznacza każdą inną osobę określoną jako „funkcjonariusz publiczny” w prawie wewnętrznym państwa-strony.

Zgodnie z Konwencją ONZ każde z państw powinno określić podmioty wchodzące w skład organów pełniących wyżej wymienione funkcje. Pojęcie to dotyczy funkcjonariuszy z wyboru, jak policjantów, urzędników celnych, członków sił zbrojnych, sędziów, prokuratorów, członków parlamentu i innych urzędników publicznych. Wyrażono pogląd, że pojęcie to dotyczy także osób, które w danym momencie nie wykonują funkcji publicznej, lecz są w położeniu, w którym będą wykonywać funkcję publiczną w późniejszym czasie ${ }^{49}$.

Także Protokół dodatkowy posługuje się metodą mieszaną. Rozszerza on zakres stosowania Konwencji do czynów korupcyjnych dotyczących arbitrów i sędziów przysięgłych. Protokół ten powstał m.in. w celu wyjaśnienia ewentualnych wątpliwości dotyczących możliwości stosowania do

${ }^{48}$ Legislative guide for the implementation of the United Nations Convention against corruption, United Nations Office on Drugs and Crime, New York 2006, www.unodc.org [dostęp: 13.06.2015 r.], s. 11.

${ }^{49}$ M. Kubiciel, Core Criminal Law Provisions in the United Nations Convention Against Corruption, „International Criminal Law Review” 2009, nr 9, s. 143. 
nich postanowień Konwencji odnoszących się do sędziów ${ }^{50}$. Protokół dodatkowy kryminalizuje: 1) łapownictwo arbitrów krajowych (art. 2 i art. 3) i 2) łapownictwo sędziów przysięgłych krajowych (art. 5).

Definiując pojęcia „,arbiter" i „,sędzia przysięgły" Protokół dodatkowy, po pierwsze, nakazuje rozumieć je stosownie do prawa wewnętrznego stron, po drugie nadaje im znaczenie autonomiczne ustalając standardy minimalne. Zgodnie z tymi definicjami „arbiter" obejmuje osoby, które na podstawie porozumienia o arbitrażu są uprawnione do wydania prawnie wiążącej decyzji w sporze między stronami porozumienia. Mogą oni działać indywidualnie lub jako część trybunału arbitrażowego ${ }^{51}$. Pojęcie „sędziego przysięgłego" odnosi się do osób, które działają jako członkowie kolegialnego ciała odpowiedzialnego za podejmowanie decyzji co do winy oskarżonego w ramach procesu karnego, bez względu na to, jak to pojęcie definiuje prawo krajowe. Strony Protokołu, które stosują szersze pojęcie "sędziego przysięgłego", zobowiązane są do kryminalizacji korupcji tych osób w tym szerszym znaczeniu ${ }^{52}$.

Termin „porozumienie o arbitrażu”, występujący w definicji arbitra, należy rozumieć jako klauzulę generalną obejmującą wszelkiego rodzaju porozumienia, odnoszące się do prawa krajowego (cywilnego, handlowego i innego), w których strony decydują poddać się arbitrażowi. Nie ma znaczenia, czy arbitrzy działają samodzielnie czy w ramach sądu arbitrażowego, muszą być jednak niezawiśli w wyrokowaniu, a ich decyzje mogą być przedmiotem odwołań ${ }^{33}$.

Odnośnie do „sędziów przysięgłych”, podkreślając wagę podejmowanych decyzji oraz honorowy (niepłatny) charakter ich pracy, uznano, że

${ }^{50} \mathrm{~W}$ trakcie końcowych negocjacji nad Konwencją karnoprawną pojawił się problem, jak traktować korupcję arbitrów. Zgadzano się, że zachowania takie powinny być kryminalizowane postanowieniami Konwencji, z jednej strony z powodu wagi podejmowanych przez nich decyzji (podobnych do zadań pełnionych przez sędziów), z drugiej z powodów ekonomicznych. Poglądy co do tego, czy korupcja arbitrów jest regulowana przez Konwencje - a jeśli tak, to którymi postanowieniami - nie były jednolite. Po pierwsze, część delegatów uznała pojęcie arbitra za odpowiadające pojęciu sędziego (w związku z tym zastosowanie do nich mają art. 2, 3, 5 i 11 Konwencji), inni uważali, że zastosowanie do arbitrów mają przepisy dotyczące sektora prywatnego (art. 7 i 8 Konwencji). Po drugie, pojawił się pogląd, że arbitrów nie dotyczy żadne z postanowień Konwencji.

${ }^{51}$ Explanatory Report on the Additional Protocol to the Criminal Law Convention on Corruption, European Treaty Series No. 191, www.coe.int [dostęp: 14.06.2015 r.], pkt 10,14 .

${ }^{52}$ Explanatory Report on the Additional Protocol, pkt 16.

${ }^{53}$ Explanatory Report on the Additional Protocol, pkt 11, 12. 
mogą się stać celem praktyk korupcyjnych i wymagają ochrony w takim zakresie jak profesjonalni sędziowie ${ }^{54}$, mimo iż nie zostali uznani przez wszystkich delegatów ani za sędziów, ani za osoby wykonujące funkcje sędziowskie.

W Protokole dodatkowym podkreślono, że jego postanowienia nie zobowiązują państw, które nie mają sądów arbitrażowych lub tylko sądy arbitrażowe w sprawach gospodarczych, do ich wprowadzenia lub rozszerzenia ich właściwości, ani do wprowadzenia systemu sądów przysięgłych, jeśli takowy w państwie nie istnieje ${ }^{55}$.

$\mathrm{W}$ poszczególnych definicjach zawartych $\mathrm{w}$ analizowanych dokumentach zwrócono uwagę na charakter wykonywanych funkcji i objęto nimi przede wszystkim osoby pełniące funkcje o charakterze wykonawczym, ustawodawczym i sądowniczym, a także pracowników instytucji państwowych i przedsiębiorstw państwowych. Definicje te mają wyraźnie szeroki zakres, o przynależności do grupy funkcjonariuszy decyduje charakter, rodzaj sprawowanej funkcji, jej merytoryczna zawartość, a nie tylko miejsce w hierarchii lub umocowanie formalne danej osoby ${ }^{56}$.

\section{Osoba pełniąca funkcję publiczną jako podmiot przestępstw korupcyjnych}

Protokoły: SADC i ECOWAS oraz Konwencje: ONZ, afrykańska i amerykańska oprócz definicji funkcjonariusza publicznego wprowadzają pojęcie „osoby pełniącej funkcję publiczną”, poszerzając tym samym zakres penalizacji.

Jedynie Protokół ECOWAS i Konwencja amerykańska definiują pojęcie „funkcja publiczna”. Zgodnie z Protokołem jest to działalność czasowa lub stała, płatna lub honorowa, wykonywana przez osobę fizyczną lub prawną w imieniu państwa lub pod jego kierownictwem, kontrolą lub władzą. Pojęcie „państwa” oznacza wszystkie szczeble władzy państwowej oraz

${ }^{54}$ Explanatory Report on the Additional Protocol, pkt 35.

${ }_{55}$ C. Nowak, Dostosowanie prawa polskiego do instrumentów międzynarodowych dotyczacych korupcji, Fundacja im. Stefana Batorego, Warszawa 2004, www.batory.org.pl/korupcja/ pub.htm [dostęp: 9.09.2014 r.], s. 19; Explanatory Report on the Additional Protocol, pkt 9.

${ }^{56}$ C. Nowak, Korupcja w polskim prawie karnym na tle uregulowan międzynarodowych, Warszawa 2008, s. 208. 
jego agencje. Definicja zawarta w Konwencji amerykańskiej jest zbliżona do definicji Protokołu ECOWAS i oznacza każdą działalność czasową lub stała, płatną lub honorowa, wykonywaną przez osobę fizyczną w imieniu państwa lub służbie państwa lub jego instytucji na jakimkolwiek poziomie jego organizacji.

Zgodnie z Konwencją ONZ osoba wykonująca funkcję publiczną jest to osoba działająca dla agencji publicznej lub przedsiębiorstwa państwowego bądź pełniąca służbę publiczną w rozumieniu prawa wewnętrznego państwa-strony i zgodnie z zastosowaniem właściwego prawa państwa-strony. Definicja ta dotyczy osób wykonujących pewne funkcje bez względu na ich status. Funkcja publiczna jest to jakakolwiek działalność w publicznym interesie delegowana przez państwo osobie fizycznej lub prawnej. Funkcjonariusz przedsiębiorstwa państwowego będzie uważany za wykonującego funkcję publiczną dopóki przedsiębiorstwo nie będzie działać na komercyjnych zasadach, na warunkach będących odpowiednikiem przedsiębiorstw prywatnych. Zgodnie $\mathrm{z}$ tą interpretacją, osoba pracująca w przedsiębiorstwie państwowym, które nie korzysta z preferencyjnych subsydiów lub innych prawnych lub finansowych przywilejów, nie będzie uważana za funkcjonariusza publicznego ${ }^{57}$.

Słowo „publiczny” ma znaczenie jednakowe zarówno w zestawieniu „funkcjonariusz publiczny", jak i w zestawieniu "funkcja publiczna"58. Wyznacza ono pewną sferę, w której określone działania wykonują określone osoby pełniące lub niepełniące funkcji, będące lub niebędące funkcjonariuszami ${ }^{59}$. W sferze publicznej znajduje się działalność organów administracji publicznej, wymiaru sprawiedliwości oraz innych państwowych jednostek organizacyjnych oraz organizacji społecznych.

W sferze publicznej można pełnić funkcje lub czynności zawodowe albo wykonywać tylko „czynności usługowe”. „Pełnienie funkcji” jest to działalność mająca charakter administracyjny - zarządzanie, nadzór, kontrola, wydawanie decyzji lub współdziałanie w ich wydawaniu. Nie jest pełnieniem funkcji praca fizyczna, np. praca produkcyjna $\mathrm{w}$ fabryce, sprzątanie w biurze. Podobnie nie jest pełnieniem funkcji praca umysłowa niemająca charakteru administracyjnego, np. sporządzanie projektów technicznych przez inżyniera, czynności lecznicze wykonywane przez le-

${ }^{57}$ M. Kubiciel, Core Criminal, s. 144.

58 T. Kanty, Glosa do postanowienia Sadu Najwyższego z dnia 30 września 2010 r., I KZP 16/10, „Gdańskie Studia Prawnicze - Przegląd Orzecznictwa” 2011, nr 3, s. 145.

${ }_{59}$ L. Gardocki, O podmiocie łapownictwa, „Państwo i Prawo” 1971, nr 5, s. 811. 
karza itp. Funkcjonariusze publiczni stanowią węższą grupę wydzieloną w zasadzie spośród osób pełniących funkcje publiczne.

W świetle prawa polskiego eksplikację zwrotu „osoba pełniąca funkcję publiczną" zawiera art. $115 \S 19$ k.k. Jako osobę pełniącą funkcję publiczną wymienia członka organu samorządowego - samorząd zawodowy. W art. 17 ust. 2 Konstytucji $\mathrm{RP}^{60}$ przewidziano możliwość tworzenia innych rodzajów samorządu. Dotyczy to przede wszystkim szeroko rozumianego samorządu gospodarczego ${ }^{61}$, np. samorządu rzemiosła, samorządu ubezpieczycieli, izb rolniczych, izb gospodarczych czy samorządu pracowniczego. Ustawowe umocowania mają również samorządy studencki i uczniowski, w których skład mogą wchodzić również osoby uznawane na gruncie prawa karnego za dorosłe. Osobą pełniącą funkcję publiczną jest członek organu któregokolwiek z wymienionych samorządów.

Przyjąć należy, że ustawodawca zawęził pojęcie „organu samorządowego" wyłącznie do organów samorządów mających swe umocowanie ustawowe. Nie powinno ono być rozszerzane na różnego typu organizacje o charakterze quasi-samorządowym powstałe $\mathrm{w}$ wyniku dobrowolnych umów, związków towarzyskich lub zawodowych, które nie posiadają formalnego umocowania prawnego, brak takiego umocowania może też być uznany za brak formalnej podstawy dla uznania określonej instytucji za samorządową. Pomimo powyższych zastrzeżeń, kodeksowe zdefiniowanie pojęcia „pełnienie funkcji publicznej” należy uznać za szerokie. Wyrażono pogląd, że jest to zbyt szerokie rozumienie, gdyż może odnosić się do wszelkich czynów podejmowanych przez członka organu samorządu, niezależnie od publicznoprawnego charakteru takich działań ${ }^{62}$. Zgodnie z poglądem prezentowanym $w$ literaturze przedmiotu, podmiotem przestępstwa łapownictwa należy obejmować jedynie: członka organu samorządu korporacyjnego kierującego lub administrującego sprawami samorządu korporacji oraz członka, który równocześnie, w zakresie swych obowiązków wynikających z ustawy, podejmuje decyzje o charakterze publicznoprawnym, tj. wywierające skutki prawne „na zewnątrz” poza

${ }^{60}$ Konstytucja Rzeczypospolitej Polskiej z dnia 6 kwietnia 1997 r. (Dz. U. Nr 78, poz. 483 z późn. zm.).

${ }^{61}$ Zob. M. Rogalski, Prawnokarna definicja funkcjonariusza publicznego oraz osoby petniacej funkcję publiczna w administracji samorządowej, "Samorząd Terytorialny” 2005, nr 3, s. 32.

${ }^{62}$ J. Potulski, Komentarz do art. 115 kodeksu karnego, [w:] J. Potulski, Komentarz do ustawy z dnia 13 czerwca 2003 r. o zmianie ustawy - Kodeks karny oraz niektórych innych ustaw, Lex nr 74313. 
sferą korporacyjna, nawet jeśli decyzje takie ograniczone są personalnie jedynie do osób wchodzących w skład korporacji63.

Zgodnie z Kodeksem karnym osobą pełniącą funkcję publiczną jest także osoba zatrudniona w jednostce organizacyjnej dysponującej środkami publicznymi, chyba że wykonuje wyłącznie czynności usługowe. Obszerny katalog środków publicznych zawiera treść art. 5 ustawy o finansach publicznych z dnia 27 sierpnia $2009 \mathrm{r} \cdot{ }^{64} \mathrm{~W}$ tym kontekście wyjaśnienia wymaga pojęcie „dysponowanie środkami publicznymi”. Ustawodawca zdefiniował pojęcie "osoba pełniąca funkcję publiczną", posługując się kryterium dysponowania środkami publicznymi przez jednostkę, w ramach której wykonuje zadania dana osoba, zatem brak możliwości uznania składników majątkowych tej jednostki za środki publiczne wyklucza możliwość uznania takiej osoby za osobę pełniącą funkcję publiczną ${ }^{65}$. Można przyjąć, że każde dysponowanie środkami publicznymi nie może być niczym innym, jak tylko ich przeznaczaniem na określone w ustawie o finansach publicznych cele - nie "publiczność" realizowanych zadań, lecz charakter wykorzystywanych lub pozostających w dyspozycji danej jednostki środków przesądza o publiczności funkcji ${ }^{66}$. Na zakres pojęcia „osoby pełniącej funkcję publiczną" wpływ ma orzecznictwo Sądu Najwyższego, zgodnie z którym funkcję publiczną pełni m.in.: dyrektor przedsiębiorstwa państwowego ${ }^{67}$, prezes spółdzielni mieszkaniowej ${ }^{68}$,

${ }^{63}$ M. Filar, Zakres pojęciowy znamienia petnienie funkcji publicznej na gruncie art. 228 k.k., „Palestra” 2003, nr 7-8, s. 66.

${ }^{64}$ Ustawa z dnia 27 sierpnia 2009 r. o finansach publicznych (Dz. U. Nr 157, poz. 1240 z późn. zm.).

${ }^{65}$ P. Kardas, Zatrudnienie w jednostce organizacyjnej dysponujacej środkami publicznymi jako ustawowe kryterium wyznaczajace zakres znaczeniowy pojęcia "osoba pełniaca funkcje publiczna". Rozważania na tle modeli interpretacyjnych reprezentowanych w piśmiennictwie karnistycznym oraz orzecznictwie Sądu Najwyższego, "Czasopismo Prawa Karnego i Nauk Penalnych" 2005, nr 1, s. 23 i n.

${ }^{66}$ P. Kardas, Kontrowersje wokót pojęcia „osoba petniaca funkcje publiczna”. Rzecz o kreatywnej wykładni przyjmowanej w orzecznictwie oraz granicach zakresowych typu czynu zabronionego określonych w ustawie, "Czasopismo Nauk Penalnych i Prawa Karnego" 2011, nr 2, s. 79.

${ }^{67}$ Uchwała składu 7 sędziów Sądu Najwyższego z 18 października 2001 r., I KZP 9/01, „Orzecznictwo Sądu Najwyższego Izba Karna i Wojskowa” 2001, nr 11-12, poz. 87, z glosą O. Górniok, „Orzecznictwo Sądów Polskich” 2002, z. 4, poz. 45.

${ }^{68}$ Uchwała składu 7 sędziów Sądu Najwyższego z 28 marca 2002 r., I KZP 35/01, "Orzecznictwo Sądu Najwyższego Izba Karna i Wojskowa” 2002, nr 5-6, poz. 29, z glosami O. Górniok i J. Skorupki, „Orzecznictwo Sądów Polskich” 2003, z. 1, poz. 7. 
upoważnieni przedstawiciele przedsiębiorstwa energetycznego dokonujący kontroli legalności poboru energii elektrycznej ${ }^{69}$.

Funkcję publiczną pełni również nauczyciel akademicki, którego zachowanie związane $\mathrm{z}$ wykonywaniem przez niego obowiązków, o jakich mowa w ustawie o szkolnictwie wyższym ${ }^{70}$, stanowi realizację jednego z konstytucyjnych zadań państwa ${ }^{71}$ i spełnia kryterium pełnienia funkcji publicznej. Zachowanie nauczyciela akademickiego zatrudnionego w wyższej uczelni nieposiadającej statusu uczelni państwowej nie jest uznane za „pełnienie funkcji publicznej”, gdyż uczelnia ta nie jest ,jednostką organizacyjną dysponującą środkami publicznymi"72; odmiennie prezentuje się sytuacja gdy nauczyciel akademicki pełni jednocześnie funkcję związaną z administrowaniem tą uczelnią ${ }^{73}$.

Pod pojęciem „osoby zatrudnionej” użytej w definicji osoby pełniącej funkcję publiczną należy rozumieć osobę pozostającą w stosunku pracy $\mathrm{w}$ jednej z wymienionych $\mathrm{w}$ Kodeksie pracy $^{74}$ form, tj. umowy o pracę, powołania, wyboru, mianowania i spółdzielczej umowy o pracę $e^{75}$, nawet jeśli dotyczy to ułamkowej części etatu. Dopuszczalne jest również rozszerzenie pojęcia „zatrudnienie” o współpracę z daną jednostką będącą efektem zobowiązania o charakterze cywilnoprawnym. Wymaga się ustaleń faktycznych co do zakresu uprawnień mogących określać treść wykonywanych zadań ${ }^{76}$.

Kierując się wykładnią gramatyczną nie należy ograniczać zakresu pojęcia „osoba pełniąca funkcję publiczną" do osób zajmujących stano-

${ }^{69}$ Postanowienie Sądu Najwyższego z 15 listopada 2002 r., IV KKN 570/99, „Orzecznictwo Sądu Najwyższego Izba Karna i Wojskowa” 2003, nr 1-2, poz. 10, z glosą R.A. Stefańskiego, „Orzecznictwo Sądów Polskich” 2003, z. 9, poz. 106.

${ }^{70}$ Ustawa z dnia 27 lipca 2005 r. - Prawo o szkolnictwie wyższym (tekst jedn. Dz. U. z 2012 r. poz. 572 z późn. zm.), art. 111.

${ }^{71}$ Art. 70 ust. 1 Konstytucji RP.

${ }^{72}$ Zob. postanowienie Sądu Najwyższego z 25 czerwca 2004 r., V KK 74/04, „Orzecznictwo Sądu Najwyższego Izba Karna i Wojskowa" 2004, nr 7-8, poz. 79.

${ }^{73}$ W. Cieślak, M. Górowski, Glosa do postanowienia Sądu Najwyż̇szego z 25 czerwca 2004 r., V KK 74/04, „Palestra” 2006, nr 1-2, s. 252.

${ }^{74}$ Ustawa z dnia 26 czerwca 1974 r. - Kodeks pracy (tekst jedn. Dz. U. z 2016 r. poz. 1666 z późn. zm.).

${ }^{75}$ Zob. J. Sieńczyło-Chlabicz, Prawo do ochrony sfery życia prywatnego osób publicznych w świetle polskiej doktryny i orzecznictwa, „Przegląd Ustawodawstwa Gospodarczego” 2005, nr 2 s. 6 i n.

${ }^{76}$ R.A. Stefański, Osoba petniaca funkcje publiczna jako podmiot przestępstwa łapownictwa, „Prokuratura i Prawo” 2000, nr 11, s. 135 i n. 
wiska kierownicze $\mathrm{w}$ wymienionych jednostkach organizacyjnych ${ }^{77}$, choć prezentowane są także stanowiska odmienne ${ }^{78}$. Orzecznictwo dopuszcza możliwość przyjęcia publicznego charakteru pełnionej funkcji w wypadku braku kompetencji władczych po stronie określonego podmiotu ${ }^{79}$. Wątpliwości mogą się pojawić w odniesieniu do osób działających na pograniczu „czynności usługowych” i innych obowiązków pracowniczych. Przykładem takiego stanowiska jest asystentka, sekretarka osób zarządzających. Przy takim podejściu możliwe jest np. objęcie odpowiedzialnością karną za łapownictwo pracownika sekretariatu sądowego (czy też innego organu szeroko pojętego wymiaru sprawiedliwości i organów ścigania), który w zamian za otrzymaną korzyść majątkowa, wykorzystując swoją funkcję, bezpodstawnie przyspiesza lub opóźnia podejmowanie decyzji przez właściwe do tego osoby, np. sędziego lub prokuratora ${ }^{80}$.

Oceny zachowań tych osób nie można podejmować in abstracto. Są bowiem sytuacje, gdy obowiązki asystentki (asystenta) dalece wykraczają poza charakter usługowy i mogą dotyczyć istotnych i znaczących zagadnień $\mathrm{w}$ odniesieniu do dysponowania środkami publicznymi ${ }^{81}$.

\section{Podmioty zagraniczne jako podmioty przestępstw korupcyjnych}

Zapewniając respekt instytucjom demokratycznym, niezależnie od tego, czy mają charakter krajowy, zagraniczny czy międzynarodowy, niektóre dokumenty poszerzają krąg podmiotów odpowiedzialnych za przestępstwa korupcyjne. Główna uwaga skupiona jest na zagranicznych funkcjonariuszach publicznych i funkcjonariuszach organizacji międzynarodowych. W okresie globalizacji struktur finansowych i gospodarczych oraz integracji rynków krajowych, decyzje oraz inwestycje podejmowane

77 J. Skorupka, Podstawy karania korupcji w kodeksie karnym de lege lata i de lege ferenda (wybrane zagadnienia), „Państwo i Prawo” 2003, nr 12 s. 78 i n.; M. Szafraniec, Przestępstwo łapownictwa w świetle ostatniej nowelizacji, „Palestra” 2004, nr 3-4, s. 115.

${ }_{78}$ M. Filar, Zakres pojęciowy, s. 68.

79 J. Potulski, Glosa do postanowienia Sądu Najwyższego z dnia 30 września 2010 r., I KZP 16/10, "Gdańskie Studia Prawnicze - Przegląd Orzecznictwa” 2011, nr 2, s. 143.

${ }^{80}$ M.G. Węglowski, Pojęcie "funkcji publicznej" w aspekcie przestępstwa łapownictwa, „Prokuratura i Prawo” 2003, nr 7-8, s. 26 i n.

${ }^{81}$ J. Potulski, Komentarz do art. 115 kodeksu karnego, Lex nr 74313. 
w jednym państwie wywierają wpływ w innym. Multinarodowe korporacje i międzynarodowi inwestorzy odgrywają dziś w gospodarce znaczącą rolę. Zarówno w ich interesie, jak i interesie całej globalnej gospodarki jest utrzymanie jawnych i uczciwych ról współzawodnictwa. Celem kryminalizacji w odniesieniu do tej grupy podmiotów jest zapewnienie jawności i uczciwości w procesie podejmowania decyzji dotyczących zarządzania publicznymi sprawami zagranicznymi. Uregulowania te mają na celu ochronę uczciwego współzawodnictwa w biznesie, a także ochronę interesu prawnego jawności i bezstronności w procesie podejmowania decyzji w organizacjach międzynarodowych, które zgodnie ze swym szczególnym mandatem prowadzą działania w interesie państw członkowskich.

Konwencje: karnoprawna i ONZ zobowiązują strony do kryminalizacji sprzedajności i przekupstwa nie tylko krajowych, ale również zagranicznych funkcjonariuszy publicznych oraz funkcjonariuszy organizacji międzynarodowych.

Konwencja OECD, obejmująca ten sam zakres podmiotowy, ogranicza się do penalizacji przekupstwa (strony czynnej łapownictwa). Jest to podstawowy dokument odnoszący się do zagadnienia tzw. korupcji transgranicznej w całości jemu poświęcony.

Protokół ECOWAS (art. 12) oraz Protokół SADC (art. 6) penalizują przekupstwo i sprzedajność zagranicznego funkcjonariusza publicznego z pominięciem funkcjonariuszy organizacji międzynarodowych. Konwencja amerykańska ogranicza się do penalizacji przekupstwa zagranicznego funkcjonariusza publicznego. Konwencja unijna definiując pojęcie „urzędnika” zaznacza, że obejmuje ono również urzędnika krajowego każdego innego państwa członkowskiego, tj. urzędnika (funkcjonariusza) zagranicznego.

\subsection{Zagraniczny funkcjonariusz publiczny}

Definicje zagranicznego funkcjonariusza publicznego w Konwencji ONZ (art. 2 pkt c) i Konwencji OECD (art. 1 ust. 4 pkt a) są zbieżne i oznaczają każdą osobę pełniącą obowiązki (zajmującą stanowisko - Konwencja OECD) ustawodawcze, administracyjne lub sądowe w obcym państwie, zarówno z powołania, jak i z wyboru (mianowana, jak i wybraną - Konwencja OECD). Konwencja ONZ do zagranicznych funkcjonariuszy publicznych zalicza także osoby pełniące funkcje wykonawcze. Termin „obce 
państwo" obejmuje wszystkie poziomy i jednostki rządowe, od narodowych do lokalnych ${ }^{82}$. Konwencja ONZ kryminalizuje zachowanie osób będących funkcjonariuszami publicznymi zarówno w odniesieniu do statusu, jak i funkcji. Konwencja amerykańska kryminalizuje przekupstwo zagranicznych funkcjonariuszy publicznych w związku z jakimikolwiek ekonomicznymi lub handlowymi transakcjami (art. VIII).

Zgodnie z Konwencją OECD zagraniczny funkcjonariusz publiczny to także każda osoba „pełniąca funkcję publiczną” w państwie obcym lub na rzecz państwa obcego ${ }^{83}$, zarówno w agencji publiczne ${ }^{84}$, jak i przedsiębiorstwie państwowym ${ }^{85}$. W Konwencji OECD „zagraniczny funkcjonariusz publiczny" oznacza zarówno urzędnika spółki lub przedsiębiorstwa państwowego, jak i urzędnika jakiegokolwiek przedsiębiorstwa, w którym państwo posiada pozycję dominującą. Starania do włączenia członków partii politycznych w zakres pojęcia zagranicznego funkcjonariusza publicznego nie powiodły się, co powoduje ryzyko nieefektywnej kryminalizacji w przypadku łapownictwa z pomocą partii politycznych ${ }^{86}$.

Do oceny, czy dana osoba jest zagranicznym funkcjonariuszem publicznym nie jest konieczny status funkcjonariusza publicznego według prawa państwa obcego ${ }^{87}$.

Prezentowane definicje mają charakter autonomiczny. Posiadają zarówno walor obiektywny, odnoszą się bowiem do usytuowania danej osoby w strukturach państwa, jak i subiektywny, obejmują bowiem także faktyczne wypełnianie zadań przez tę osobę na rzecz aparatu państwowe-

${ }^{82}$ Legislative guide for the implementation of the United Nations Convention, s. 11.

83 "Obce państwo" oznacza każdą jednostkę lub zagraniczny obszar zorganizowany, taki jak terytoria autonomiczne lub oddzielne terytoria celne - Commentaries on the OECD Convention on Combating Bribery of Foreign Public Off icials in International Business Transactions, OECD 2011, www.oecd.org [dostęp: 14.06.2015 r.], pkt 18.

${ }^{84}$ "Agencja publiczna" to każda jednostka ustanowiona zgodnie z prawem publicznym w celu przeprowadzania zadań specjalnych w publicznym interesie - Commentaries on the OECD Convention, pkt 13.

85 „Przedsiębiorstwo publiczne” to każde przedsiębiorstwo, bez względu na jego formę prawna, nad którym rząd sprawuje, bezpośrednio lub pośrednio, dominujący wpływ. Wpływ taki sprawuje, inter alia, kiedy posiada większość kapitału przedsiębiorstwa, kontroluje większość głosów pochodzących z przydziału akcji przedsiębiorstwa lub gdy ma prawo wyznaczania większości członków władz administracyjnych lub kontrolnych przedsiębiorstwa - Commentaries on the OECD Convention, pkt 14.

${ }^{86} \mathrm{H}$. Shams, The Fight Against Extraterritorial Corruption and the Use of Money Laundering Control, "Law and Business Review of the Americas” 2001, nr 7, s. 100.

${ }^{87}$ M. Kubiciel, Core Criminal Law, s. 152. 
go $^{88}$. Konwencja OECD przez „funkcję publiczną" rozumie każdą działalność w publicznym interesie, zleconą przez państwo obce, tj. wykonywanie zadań zleconych powiązanych z zamówieniami publicznymi ${ }^{89}$.

Zagraniczny funkcjonariusz publiczny w Protokole ECOWAS oznacza jakąkolwiek osobę wykonującą funkcję publiczną w innym państwie-stronie (art. 1).

Konwencja karnoprawna nie definiuje pojęcia „zagraniczny funkcjonariusz publiczny”. Decydującym elementem uznania funkcjonariusza za zagranicznego jest nie jego narodowość, ale fakt, że działa on w tym charakterze na podstawie prawa innego niż państwo ścigające. Ponadto Konwencja karnoprawna w odrębnym postanowieniu rozszerza krąg podmiotów zagranicznych narażonych na praktyki korupcyjne o kategorię „członków zgromadzeń przedstawicielskich zagranicznych” (art. 6), która powinna być interpretowana w świetle prawa krajowego obcego państwa ${ }^{90}$.

Zaznaczyć należy, że Protokół dodatkowy rozszerzył zakres zastosowania Konwencji karnoprawnej do czynów korupcyjnych dotyczących łapownictwa arbitrów zagranicznych i zagranicznych sędziów przysięgłych. Protokół nie zawiera definicji arbitra "zagranicznego". Decydującym elementem dla uznania arbitra za "zagranicznego" ma nie jego narodowość ale fakt, że działa on w tym charakterze na podstawie prawa innego państwa niż państwo ścigające ${ }^{91}$. Podobnie jak w przypadku arbitra zagranicznego, pojęcie „zagraniczny sędzia przysięgły” należy rozumieć jako „działający w dowolnym innym państwie”. Ponadto mutatis mutandis mają tu zastosowanie uwagi poczynione przy omówieniu uregulowań Protokołu dodatkowego dotyczącego arbitrów i krajowych sędziów przysięgłych.

Postanowienia Konwencji karnoprawnej i ONZ wykraczają poza regulacje Konwencji unijnej i Protokołu ECOWAS, gdyż kryminalizują łapownictwo zagranicznego funkcjonariusza publicznego każdego innego państwa, a nie tylko państwa członkowskiego danej organizacji.

\footnotetext{
${ }^{88}$ C. Nowak, Dostosowanie prawa polskiego do instrumentów międzynarodowych, s. 5.

${ }^{89}$ Commentaries on the OECD Convention, pkt 12.

${ }^{90}$ Explanatory Report on the Criminal, pkt 51.

${ }^{91}$ Explanatory Report on the Additional Protocol, pkt 33.
} 


\subsection{Funkcjonariusz organizacji międzynarodowej}

Stosunki międzynarodowe i prawo międzynarodowe ulegają rozwojowi i ciągłemu wzbogaceniu. Ciężar współpracy międzynarodowej został przesunięty z dyplomatycznych kontaktów wielostronnych państw na forum „dyplomacji parlamentarnej”, prowadzonej w łonie organizacji międzynarodowych. Prawdziwym fenomenem tego okresu jest jednak powstanie i rozwój międzynarodowej funkcji publicznej. Tysiące funkcjonariuszy pracuje $\mathrm{w}$ organizacjach międzynarodowych, wykonując statutową działalność, a ich liczba stale się powiększa ${ }^{92}$.

Zgodnie ze stanowiskiem prezentowanym w literaturze przedmiotu funkcjonariuszem (międzynarodowym) organizacji międzynarodowej jest osoba zobowiązana na mocy umowy międzynarodowej do wykonywania funkcji w organie organizacji międzynarodowej w interesie organizacji. Funkcjonariusz międzynarodowy wykonuje międzynarodową funkcję publiczną. Nie może on zatem pełnić funkcji w żadnym państwie. Jest on niezależny od państw członkowskich, w wykonywaniu funkcji podlega jedynie organizacji międzynarodowej ${ }^{93}$.

Zgodnie z art. 9 Konwencji karnoprawnej funkcjonariusz organizacji międzynarodowej jest to ,jjakikolwiek funkcjonariusz lub inny pracownik kontraktowy w rozumieniu przepisów dotyczących personelu, jakiejkolwiek publicznej międzynarodowej lub ponadnarodowej organizacji lub instytucji, których strona jest członkiem, oraz jakiejkolwiek osoby, czy to oddelegowanej czy też nie, wykonującej funkcje odpowiadające funkcjom wykonywanym przez takich funkcjonariuszy lub pracowników".

Występują tu dwie główne kategorie urzędników: 1) funkcjonariusze i inni kontraktowi pracownicy, którzy zgodnie z przepisami dotyczącymi personelu mogą być czasowymi lub stałymi członkami personelu, bez względu na długość ich zatrudnienia przez organizacje, mający identyczne obowiązki i odpowiedzialność uregulowane przez kontrakt, oraz 2) członkowie personelu, którzy są oddelegowani (oddani do dyspozycji organizacji przez rząd lub jakąkolwiek publiczną lub prywatną jednostkę) do prowadzenia funkcji odpowiadających tym wykonywanym przez urzędników lub pracowników kontraktowych. Ponadto art. 9 ogranicza

\footnotetext{
${ }_{92}$ G. Grabowska, Funkcjonariusze międzynarodowi, Katowice 1988, s. 17.

93 J. Barcik, T. Srogosz, Prawo międzynarodowe publiczne, Warszawa 2007, s. 150.
} 
zobowiązanie do tych przypadków łapownictwa, w które zaangażowane są osoby będące pracownikami organizacji, których są członkami ${ }^{94}$.

Ujęcie „międzynarodowe lub ponadnarodowe organizacje”"95 oznacza organizacje rządowe, a nie jednostki lub organizacje prywatne. Oznacza to także, iż międzynarodowe organizacje pozarządowe (NGO's) pozostają poza zakresem regulacji tego przepisu. Jednak w niektórych przypadkach do członków NGO's mogą być stosowane inne przepisy, jak np. dotyczące łapownictwa w sektorze prywatnym.

Ponadto Konwencja karnoprawna w odrębnych postanowieniach rozszerza krąg podmiotów narażonych na praktyki korupcyjne o członków międzynarodowych zgromadzeń parlamentarnych oraz sędziów i urzędników sądów międzynarodowych. Grupę przestępstw popełnianych przez członków organów parlamentarnych i sądów międzynarodowych w Konwencji karnoprawnej ustanowiono przez odwołanie do art. 2 i 3 (dotyczących przekupstwa i sprzedajności). Zróżnicowano tylko bezpośrednie dobro prawne chronione tymi postanowieniami i tym samym podmioty, o które chodzi.

Międzynarodowe zgromadzenia parlamentarne są to zgromadzenia wykonujące władzę ustawodawcza, administracyjną oraz doradczą na podstawie statutów tworzących organizacje międzynarodowe. Sprzedajność dotyczy w tym przypadku członków międzynarodowych zgromadzeń parlamentarnych (np. Zgromadzenie Parlamentarne Rady Europy) oraz organizacji ponadnarodowych (np. Parlament Europejski) ${ }^{96}$.

Zgodnie z Konwencją karnoprawną sędziowie i urzędnicy sądów międzynarodowych są to ,jakiekolwiek osoby sprawujące funkcje sędziowskie lub będące funkcjonariuszami jakiegokolwiek sądu międzynarodowego, którego jurysdykcje strona uznaje" ${ }^{\prime 97}$. Obejmuje to nie tylko „sędziów" międzynarodowych trybunałów (np. Międzynarodowego Trybunału Praw Człowieka), ale także innych funkcjonariuszy (np. prokuratorów Trybunału ONZ dla byłej Jugosławii) lub członków urzędów. Sądy

${ }^{94}$ Explanatory Report on the Criminal, pkt 59, 60.

95 Organizacje międzynarodowe, jak Rada Europy; organizacja ponadnarodowa, jak Unia Europejska.

96 Explanatory Report on the Criminal, pkt 62.

${ }^{97} \mathrm{Na}$ temat sądów międzynarodowych zob. Ch. Brown, The evolution and application of rules concerning independence of the "international judiciary", "The Law and Practice of International Courts and Tribunals" 2003, nr 2, s. 63 i n. 
arbitrażowe nie mieszczą się w pojęciu "sądy międzynarodowe", gdyż nie sprawują funkcji sądowniczej w imieniu państw ${ }^{98}$.

Sędziowie międzynarodowych trybunałów administracyjnych (Organizacji Narodów Zjednoczonych, Międzynarodowej Organizacji Pracy) wykonują zadania międzynarodowe, w tym samym czasie zachowując prawo do występowania $\mathrm{w}$ charakterze funkcjonariuszy państwowych. Zdaniem niektórych przedstawicieli nauki przedmiotu, trudno uznać ich za funkcjonariuszy międzynarodowych; wprowadzają oni określenie agentów międzynarodowych ${ }^{99}$.

Podczas prac nad Protokołem dodatkowym dyskutowano również kwestię „arbitrów międzynarodowych”. Zdecydowano jednak nie ustanawiać odrębnego artykułu dotyczącego tych osób. Sprawa ta może dotyczyć głównie arbitrów publicznych organizacji międzynarodowych. W przypadku powstania ewentualnych luk prawnych istnieje możliwość stosowania art. 9 Konwencji karnoprawnej dotyczącego „łapownictwa funkcjonariuszy międzynarodowych"100.

Kryminalizację zachowań korupcyjnych funkcjonariuszy organizacji międzynarodowych przewidziano również w Konwencjach: ONZ, unijnej i OECD.

Zgodnie z art. 2 pkt c Konwencji ONZ „funkcjonariusz publicznej organizacji międzynarodowej” oznacza międzynarodowego urzędnika państwowego lub każdą osobę upoważnioną przez daną organizację do występowania w jej imieniu. Organizacje międzynarodowe utworzone przez osoby prywatne nie wchodzą w zakres powyższej definicji. Nie jest też wymagane w świetle Konwencji, by państwo-strona Konwencji było członkiem organizacji międzynarodowej, w łonie której doszło do korupcji101.

Zgodnie $\mathrm{z}$ art. 1 pkt b Konwencji unijnej, posługującej się definicją autonomiczna, „urzędnik wspólnotowy oznacza: 1) każdą osobę będącą urzędnikiem lub innym pracownikiem zatrudnionym na podstawie umowy o pracę w rozumieniu regulaminu pracowniczego urzędników Wspólnot Europejskich, lub warunków zatrudnienia innych pracowników Wspólnot Europejskich oraz 2) każdą osobę oddelegowaną do Wspólnot Europejskich przez Państwa Członkowskie lub każdy organ publiczny lub prywatny, który wykonuje czynności równorzędne z tymi, które są

\footnotetext{
98 Explanatory Report on the Criminal, pkt 63.

99 Szerzej na ten temat zob. G. Grabowska, Funkcjonariusze, s. 16.

100 Explanatory Report on the Additional Protocol, pkt 34.

101 M. Kubiciel, Core Criminal Law, s. 152.
} 
wykonywane przez urzędników, lub innych pracowników Wspólnot Europejskich". Przedmiotem ochrony przepisów Konwencji unijnej jest dobro Unii Europejskiej oraz dobro państw członkowskich Unii, lecz nie żadnych innych państw lub organizacji międzynarodowych.

Z kolei pojęcie "zagranicznego funkcjonariusza publicznego" w Konwencji OECD obejmuje swym zakresem również „przedstawicieli publicznej organizacji międzynarodowej” (art. 1 in fine). „Publiczna organizacja międzynarodowa" oznacza każdą organizację międzynarodową utworzoną przez państwa, rządy lub inne publiczne międzynarodowe organizacje, bez względu na formę organizacyjną i zakres kompetencji. Oznacza to, że Konwencja ma zastosowanie nie tylko do urzędników obcych państw, ale i organizacji międzynarodowych, takich jak np. Unia Europejska, Światowa Organizacja Handlu czy sama OECD, jeśli urzędnicy ci zostaną przekupieni w warunkach i w celu opisanym w Konwencji ${ }^{102}$.

Organizacjami międzynarodowymi o szczególnym charakterze są Międzynarodowy Komitet Olimpijski (MKO) oraz Międzynarodowa Federacja Piłki Nożnej (FIFA). Skandale korupcyjne, do jakich doszło w strukturach MKO, zwłaszcza w 1998 r. - związany z uzyskaniem prawa organizacji igrzysk zimowych w 2002 r. w Salt Lake City, a także w strukturach FIFA - zwłaszcza dotyczących łapówek wręczanych w związku z przyznaniem mistrzostw świata RPA w 2010 r., a także podejrzeniem uzyskania prawa organizacji mistrzostw w Rosji i w Katarze w 2018 i 2022 r., w sposób korupcyjny, uzasadniają zwrócenie na te organizacje uwagi.

Członkowie tych organizacji nie są objęci zakresem definicji zagranicznego funkcjonariusza publicznego. Nie mają oni władzy ustawodawczej, administracyjnej ani sądowniczej w zagranicznym państwie (jako części ich działalności), nie wykonują funkcji publicznej w innym państwie, nie są również częścią agencji rządowej ani publicznego przedsiębiorstwa.

Organizacje te składają się z przedstawicieli różnych państw, pomimo usytuowania ich w Szwajcarii ze względu na swój charakter wpływają $\mathrm{w}$ wymiarze gospodarczym na państwa goszczące. $\mathrm{W}$ tym zakresie mieszczą się w pojęciu „międzynarodowej” organizacji. Nie są one jednak „publicznymi” organizacjami międzynarodowymi. Analizowane dokumenty do „publicznej organizacji międzynarodowej” zaliczają międzynarodowe organizacje utworzone przez państwa, rządy lub inne publiczne organizacje. Analizowane dokumenty nie mają zatem do nich zastosowa-

\footnotetext{
${ }^{102}$ Commentaries on the OECD Convention, pkt 17.
} 
nia ${ }^{103}$. Brak możliwości zakwalifikowania takich organizacji jako objętych zakresem odpowiedzialności na podstawie analizowanych dokumentów należy uznać za wadę dokumentów, w związku z czym celowe wydają się działania zmierzające do rozszerzenia zakresu ich zastosowania.

\section{Podmioty łapownictwa w sektorze prywatnym}

Od klasycznych odmian łapownictwa, łapownictwo w sektorze prywatnym różni się kręgiem podmiotów sprawczych oraz podmiotu bezpośredniego oddziaływania. Dokumentami odnoszącymi się do zagadnienia łapownictwa w sektorze prywatnym są konwencje: karnoprawna (art. 7), afrykańska (art. 4 ust. 1 pkt e), ONZ (art. 21) oraz Protokoły: ECOWAS (art. 6 ust. 5), SADC (art. 3), a także Decyzja ramowa.

Zgodnie $\mathrm{z}$ analizowanymi dokumentami międzynarodowymi podmiotem łapownictwa w sektorze prywatnym jest „osoba, która kieruje lub pracuje, w jakimkolwiek charakterze, dla podmiotu sektora prywatnego". Charakteryzując podmiot sprzedajności gospodarczej posłużono się sformułowaniami ogólnymi i nieostrymi, co sprawia, iż wyznaczenie kręgu podmiotów sprawczych wywoływać może pewne trudności i kontrowersje $\mathrm{e}^{104}$.

Nie wprowadzono warunku posiadania przez podmiot sektora prywatnego osobowości prawnej lub też tzw. ułomnej albo prawnohandlowej osobowości prawnej. Należy zatem przyjąć, że pod pojęciem „podmiotu sektora prywatnego" rozumie się wszelkiego rodzaju struktury organizacyjne, za pośrednictwem których prowadzona jest działalność gospodarcza. Jest to najszerszy z możliwych sposobów określenia podmiotu gospodarczego. Na gruncie tych uregulowań podmiot charakteryzuje jedynie zakres jego działalności, tj. wykonywanie działalności gospodarczej.

Pojęcie podmiotu należącego do sektora prywatnego odnosi się do przedsiębiorstw, korporacji i wszelkich innych podmiotów, które w całości lub w znacznej części są własnością podmiotów prywatnych, w tym

103 A. Saloufakos-Parsons, "Going for the Gold": an Application of the OECD Bribery Convention to the Olympic Games Scandals, "California Western International Law Journal" 2001, nr 31, s. 307-309.

${ }^{104}$ Por. A. Wąsek (red.), Komentarz do kodeksu karnego. Część szczególna, t. II, Warszawa 2004, s. 1038. 
także podmiotów nieposiadających osobowości prawnej, a nawet jednostek organizacyjnych - pojęcie ,jednostka” rozumiane jest również jako pojedyncza osoba ${ }^{105}$. Z zakresu tych regulacji wyłączone są jednostki będące własnością państwa ${ }^{106}$.

W świetle polskiego prawa karnego podmiotami sektora prywatnego są wszystkie uregulowane w Kodeksie spółek handlowych ${ }^{107}$ spółki prawa handlowego (osobowe i kapitałowe), przedsiębiorstwa państwowe, fundacje, stowarzyszenia, spółdzielnie. Podmiotem tym jest również spółka cywilna, chociaż nie posiada ona osobowości prawnej, zaś przepisy ustawy nie przyznają jej zdolności prawnej. Spółka cywilna ma jednak określoną strukturę wewnętrzną oraz zasady prowadzenia jej spraw i reprezentacji na zewnątrz.

Podmiotem sektora prywatnego jest również przedsiębiorca będący osobą fizyczną (tzw. przedsiębiorca jednoosobowy), w szczególności wówczas, gdy prowadzi działalność gospodarczą w oparciu o zorganizowaną wewnętrznie strukturę, składającą się z dwu lub więcej osób, o określonych zasadach prowadzenia jej spraw i reprezentacji na zewnątrz.

Za podmiot sektora prywatnego uznać należy zarówno taką zorganizowaną strukturę, która jako całość wykonuje działalność gospodarcza, jak i określone i wyodrębnione organizacyjnie części składowe większej struktury gospodarczej, np. oddziały, działy, wydziały, zakłady itp. ${ }^{108}$

Posłużenie się $\mathrm{w}$ treści dokumentów międzynarodowych sformułowaniem „kieruje lub pracuje w jakimkolwiek charakterze” wskazuje na formalny status osoby kierującej. Osoba kierująca jest to podmiot odpowiednio usytuowany $\mathrm{w}$ strukturze wewnętrznej podmiotu sektora prywatnego, zajmujący pozycję, z którą związane są uprawnienia i obowiązki o charakterze decyzyjnym. Dokumenty nie wprowadzają wymogu odpowiedniej formy umocowania osoby pełniącej funkcję kierowniczą. Zatem pełnienie tej funkcji może wynikać $\mathrm{z}$ formalnego węzła prawnego łączącego sprawcę z jednostką organizacyjną wykonującą działalność gospodarcza, np. stosunku korporacyjnego, umowy o pracę, umowy cywilnoprawnej, może być także konsekwencją faktycznego wykonywania określonych, a mających charakter kierowniczy, czynności. W tym ostat-

105 Explanatory Report on the Criminal, pkt 54.

106 C. Nowak, Korupcja w polskim prawie, s. 235.

107 Ustawa z dnia 15 września 2000 r. - Kodeks spółek handlowych (tekst jedn. Dz. U. z 2017 r. poz. 1577).

108 Por. O. Górniok (red.), Kodeks karny. Komentarz, Warszawa 2004, s. 433. 
nim przypadku konieczne jest istnienie w strukturze podmiotu określonego zestawu kompetencji i obowiązków, które zostały powierzone konkretnej osobie.

Oprócz osób pełniących funkcje kierownicze, sprawcą przestępstwa łapownictwa $\mathrm{w}$ sektorze prywatnym może być także osoba niepełniąca takiej funkcji, ale mająca wpływ na podejmowanie decyzji związanych z działalnością jednostki organizacyjnej z racji zajmowanego stanowiska lub pełnionej funkcji. Elementem przesądzającym o możliwości zaliczenia określonych osób do kategorii podmiotów sprawczych tego przestępstwa jest w tym przypadku zakres posiadanych przez daną osobę uprawnień w toku procesu decyzyjnego, takich, które mają istotny wpływ na decyzje podejmowane w zakresie działalności podmiotu ${ }^{109}$.

Określenie sprawcy przestępstwa sprzedajności jako osoby, która z racji zajmowanego stanowiska lub pełnionej funkcji ma istotny wpływ na podejmowanie decyzji, przesądza, że nie jest konieczne wykazywanie formalnego związku takiej osoby z jednostką organizacyjną wykonującą działalność gospodarczą. W przypadku przesłanki ujętej jako "pracuje” wynika, iż związek z jednostką organizacyjną powinien mieć formalny charakter.

Osoba pełniąca funkcje kierownicze już z racji pełnienia tych funkcji posiada status sprawcy przestępstwa sprzedajności. W przypadku wykonywania pracy innej niż „kierownicza”, wydaje się konieczne wykazanie, że osoba miała istotny wpływ na podejmowanie decyzji związanych z działalnością jednostki, w której pełni określone funkcje. Dotyczy to także osób, które nie mają statusu pracownika lub zatrudnione są czasowo, np. konsultanci, agenci handlowi (umowa cywilnoprawna), lecz mogą być zobowiązani do odpowiedzialności za spółkę.

Analizowane dokumenty nie mają zastosowania do osób zajmujących się czynnościami materialno-technicznymi ${ }^{110}$. Podobnie jak w wypadku osób zaliczanych do funkcjonariuszy publicznych oraz pełniących funkcję publiczną podmiotem korupcji nie mogą być pracownicy pełniący jedynie funkcje usługowe, a nawet wykonujący czynności merytoryczne w danej jednostce, jeżeli nie mają one wpływu na decyzje związane z działalnoś-

109 Por. J. Raglewski, Odpowiedzialność karna za korupcje gospodarcza (art. 296a k.k.), „Prawo Spółek" 2005, nr 6, s. 34.

${ }_{110}$ Por. S. Parkitny, Problem korupcyjnego charakteru prezentu w obrocie gospodarczym a odpowiedzialność karna, „Nowa Kodyfikacja Prawa Karnego” 2004, nr 15, s. 119. 
cią tej jednostki ${ }^{111}$. Podmiotem sprzedajności może być jedynie osoba, która pełni funkcję kierowniczą albo z racji zajmowanego stanowiska lub pełnionej funkcji ma istotny wpływ na decyzje związane $\mathrm{z}$ działalnością takiej jednostki (np. jako radca prawny, księgowy, specjalista przygotowujący decyzje, członek organu kolegialnego). Każdy może być sprawcą przekupstwa, ale najczęściej jest to osoba reprezentująca przedsiębiorcę zainteresowana korzyściami mogącymi wynikać z tego zachowania.

\section{Podsumowanie}

Przedmiotem ochrony zagrożonym przez przestępczość korupcyjną jest przede wszystkim prawidłowa działalność administracji publicznej, tak w wymiarze państwowym, jak i międzynarodowym. Regulacje prawne dotyczące korupcji zapewnić mają jawność, uczciwość i bezstronność oraz zaufanie społeczeństwa do struktur administracyjnych instytucji państwowych i organizacji międzynarodowych. Przez działalność podlegającą ochronie należy rozumieć aktywność funkcjonariuszy danej instytucji, służącą bezpośredniej realizacji celów tej instytucji. Przedmiotem ochrony regulacji antykorupcyjnych jest również właściwe działanie podmiotów sektora prywatnego poprzez umożliwienie niezakłóconego działania gospodarki wolnorynkowej. Niemniej jednak analizowane dokumenty główny nacisk kładą na uregulowania dotyczące podmiotów sektora publicznego.

Sektor publiczny (władza publiczna) działa przez instytucje państwowe, przez które należy rozumieć organy państwowe. Organy państwowe są to organy władzy ustawodawczej, wykonawczej i sądowniczej, organy kontroli państwowej wraz z urzędami powołanymi do ich obsługi, a także instytucje sprawujące funkcje z zakresu zarządu państwowego (np. Narodowy Bank Polski, Zakład Ubezpieczeń Społecznych, Polska Akademia Nauk), a także inne instytucje, tj. szkoły, szpitale należące do państwa, powołane do zaspokajania potrzeb ludzi ze strony państwa ${ }^{112}$. Przez instytucje szczebla lokalnego (samorząd terytorialny) należy rozumieć organy samorządu terytorialnego (lokalnego) działające na podstawie ustawy,

111 Zob. A. Marek, Kodeks karny - komentarz, Warszawa 2005, s. 608.

112 A. Zoll (red.), Komentarz do kodeksu karnego Część szczególna, t. 2, Kraków 1999, s. 707. 
a także organy kontroli samorządu terytorialnego. Pojęcie funkcjonariusza publicznego (krajowego lub zagranicznego) związane jest ściśle z władzą publiczną (państwową i samorządową). Nie są natomiast funkcjonariuszami publicznymi osoby działające jedynie w sektorze prywatnym.

Nie jest rzeczą łatwą usunięcie wszystkich wątpliwości i trudności, jakie łączą się ze stosowaniem przepisów definiujących pojęcie „funkcjonariusza publicznego" w dokumentach międzynarodowych, ze względu na użycie elementów ocennych, koniecznych z punktu widzenia kryminalno-politycznego, nie można w formie opisowej określić konstytutywnych elementów definiowanej nazwy ${ }^{113}$. Ze sformułowań dokumentów międzynarodowych wynika, że określenie podmiotu przestępstwa łapownictwa biernego (sprzedajność) następuje przez wskazanie pełnienia funkcji, czyli od strony czynnościowej, a nie od strony zajmowanego stanowiska.

Konwencje: amerykańska i afrykańska pomijają funkcjonariuszy organizacji międzynarodowych. Brak ten jest znaczący zwłaszcza z uwagi na ekonomiczny wpływ publicznych organizacji międzynarodowych, w szczególności wśród gospodarek rozwijających się, i wpływ, jaki mają na rozwój i pomoc humanitarną. Analizowane dokumenty pomijają funkcjonariuszy organizacji pozarządowych, którzy obecnie odgrywają znaczącą rolę zwłaszcza w państwach afrykańskich. Brak jest również obowiązku kryminalizacji zagranicznych partii politycznych i ich członków ${ }^{114}$. Konwencje karnoprawna i unijna obejmują jedynie osoby uznane w prawie krajowym za funkcjonariuszy publicznych. Nie odnoszą się do osób objętych pojęciem "osoby pełniącej funkcję o charakterze publicznym”. Definicje te obejmują swoim zakresem węższą grupę osób niż definicje zawarte w pozostałych dokumentach międzynarodowych ${ }^{115}$.

Z uwagi na konstrukcję przestępstw sprzedajności i przekupstwa, w tym w szczególności sposób określenia podmiotu sprzedajności oraz podmiotu bezpośredniego oddziaływania w przypadku przekupstwa, większość osób uczestniczących w organizacji i przeprowadzaniu profesjonalnych zawodów sportowych nie posiada statusu osoby pełniącej funkcję publiczna, a tym samym nie spełnia przesłanek podmiotowych uzasadniających odpowiedzialność za klasyczne przestępstwo łapowni-

113 Por. W. Wolter, Odpowiedzialność karna osób petniacych funkcje publiczne, „Państwo i Prawo" 1969, nr 6, s. 962.

114 Por. D. Metcalfe, The OECD Agreement to Criminalize Bribery: A Negotiation Analytic Perspective, „International Negotiation” 2000, nr 5, s. 136.

115 Por. C. Nowak, Korupcja w polskim prawie, s. 207. 
ctwa $^{116}$. Z uwagi na praktyki korupcyjne w sporcie oraz wynikające z niego negatywne konsekwencje w wielu obszarach, koniecznym wydaje się uzupełnienie regulacji międzynarodowych w tym zakresie ${ }^{117}$.

Słowa kluczowe: funkcjonariusz publiczny, funkcja publiczna, urzędnik zagraniczny, funkcjonariusz organizacji międzynarodowej, sektor prywatny, korupcja, łapownictwo

\section{Bibliografia}

Balcerzak M., Korupcja jako zagrożenie dla społeczności międzynarodowej i praw człowieka, [w:] J. Symonides (red.), Świat wobec wspótczesnych wyzwań i zagrożen, Warszawa 2010.

Banasiewicz M., Kokot R., Z problematyki odpowiedzialności karnej za bład w sztuce lekarskiej, „Nowa Kodyfikacja Prawa Karnego” 2009, nr 24.

Bantekas I., Corruption as an International Crime and Crime Against Humanity, "Journal of International Justice" 2006, nr 4.

Barańska A., Status prawny komornika sadowego i mienia kancelarii komorniczej, „Przegląd Prawa Egzekucyjnego" 2008, nr 1-2.

Barcik J., Srogosz T., Prawo międzynarodowe publiczne, Warszawa 2007.

Bodio J., Status prawny notariusza - wybrane zagadnienia, „Rejent” 2011, nr 10.

Brown Ch., The evolution and application of rules concerning independence of the "international judiciary", "The Law and Practice of International Courts and Tribunals" 2003, nr 2.

Budyn-Kulik M., Kozłowska-Kalisz P., Kulik M., Mozgawa M., Komentarz do art. 115 Kodeksu karnego, [w:] M. Mozgawa (red.), M. Budyn-Kulik, P. Kozłowska-Kalisz, M. Kulik, Kodeks karny. Komentarz, Lex nr 471719.

Cieślak W., Górowski M., Glosa do postanowienia Sąu Najwyższego z 25 czerwca 2004 r., V KK 74/04, „Palestra” 2006, nr 1-2.

Filar M., Zakres pojęciowy znamienia petnienie funkcji publicznej na gruncie art. 228 k.k., „Palestra” 2003, nr 7-8.

Gardocki L., O podmiocie łapownictwa, „Państwo i Prawo” 1971, nr 5.

Garus-Ryba J., Problem odpowiedzialności karnej lekarza za przestępstwo tapownictwa biernego, „Palestra” 2001, nr 7-8.

116 Por. P. Kardas, Zatrudnienie w jednostce organizacyjnej, s. 23 i n.

117 Szerzej na ten temat zob. A. Krzywniak, Sporne problemy zakresu kryminalizacji korupcji w sporcie profesjonalnym na tle art. $296 b$ kodeksu karnego z 1997 roku, „Nowa Kodyfikacja Prawa Karnego" 2006, nr 19, s. 14 i n.; J. Potulski, M. Ruciński, Odpowiedzialność sędziego sportowego za przyjęcie tapówki, „Prokuratura i Prawo” 2007, nr 9, s. 59 i n.; R.A. Stefański, Przestępstwo korupcji w sporcie profesjonalnym (art. $296 b$ k.k.), „Prokuratura i Prawo" 2004, nr 2, s. 60 i n. 
Gathii J.T., Defining the Relationship Between Human Rights and Corruption, „University of Pennsylvania Journal of International Law” 2009, nr 31.

Giezek J., Komentarz do art. 115 Kodeksu karnego, [w:] J. Giezek (red.), N. Kłączyńska, G. Łabuda, Kodeks karny. Część ogólna. Komentarz, Warszawa 2012.

Giezek J., Odpowiedzialność karna notariusza w świetle art. 231 kodeksu karnego, „Rejent" 2006, nr 3.

Gozdór G., Status prawno-karny pracownika ochrony, "Prokuratura i Prawo" 2001, nr 3.

Górniok O., Glosa do uchwały Sądu Najwyższego z dnia 18 października 2001 r., I KZP 9/01, „Orzecznictwo Sądów Polskich” 2002, z. 4, poz. 45.

Górniok O., Glosa do uchwaty Sądu Najwyższego z dnia 28 marca 2002 r., I KZP 35/01, „Orzecznictwo Sądów Polskich” 2003, z. 1, poz. 7.

Górniok O., Z problematyki prawnokarnej prania pieniędzy na tle ustawy z dnia 16 listopada 2000 r., "Przegląd Sądowy” 2002, nr 4.

Górniok O. (red.), Kodeks karny. Komentarz, Warszawa 2004.

Grabowska G., Funkcjonariusze międzynarodowi, Katowice 1988.

Hamilton C.K., Bribery of Public Officials, "American Criminal Law Review” 1993, nr 30.

Hurst M.K., Eliminating Bribery in International Business Transactions, "Journal of International Law and Practice" 1997, nr 6.

Jonderko M., Kilka uwag na temat statusu prawnego asesora komorniczego, „Przegląd Prawa Egzekucyjnego" 2009, nr 4-5.

Kanty T., Glosa do postanowienia Sądu Najwyższego z dnia 30 września 2010 r., I KZP 16/10, „Gdańskie Studia Prawnicze - Przegląd Orzecznictwa” 2011, nr 3.

Kardas P., Kontrowersje wokół pojęcia „osoba petniąca funkcję publiczna”. Rzecz o kreatywnej wykładni przyjmowanej w orzecznictwie oraz granicach zakresowych typu czynu zabronionego określonych w ustawie, „Czasopismo Nauk Penalnych i Prawa Karnego" 2011, nr 2.

Kardas P., Zatrudnienie w jednostce organizacyjnej dysponujacej środkami publicznymi jako ustawowe kryterium wyznaczajace zakres znaczeniowy pojęcia "osoba petniaca funkcje publiczna". Rozważania na tle modeli interpretacyjnych reprezentowanych w piśmiennictwie karnistycznym oraz orzecznictwie Sądu Najwyższego, "Czasopismo Prawa Karnego i Nauk Penalnych” 2005, nr 1.

Kłak C.P., Notariusz a przestepstwo nadużycia władzy publicznej (art. 231 k.k.). Zagadnienia materialnoprawne i procesowe, "Rejent” 2011, nr 2.

Krzywniak A., Sporne problemy zakresu kryminalizacji korupcji w sporcie profesjonalnym na tle art. $296 b$ kodeksu karnego z 1997 roku, "Nowa Kodyfikacja Prawa Karnego" 2006, nr 19.

Kubiciel M., Core Criminal Law Provisions in the United Nations Convention Against Corruption, "International Criminal Law Review” 2009, nr 9.

Kulesza J., Glosa do uchwały Sądu Najwyższego z dnia 20 czerwca 2001, IKZP 5/01, „Prokuratura i Prawo” 2002, nr 10. 
Lapidus S.E., Mogilevich M., Public Corruption, „American Criminal Law Review" 2010, nr 47.

Marek A., Kodeks karny - komentarz, Warszawa 2005.

Metcalfe D., The OECD Agreement to Criminalize Bribery: A Negotiation Analytic Perspective, „International Negotiation” 2000, nr 5.

Mozgawa M. (red.), Kodeks karny. Praktyczny komentarz, Warszawa 2007.

Nowak C., Dostosowanie prawa polskiego do instrumentów międzynarodowych dotyczacych korupcji, Fundacja im. Stefana Batorego, Warszawa 2004, w w w . batory.org.pl/korupcja/pub.htm.

Nowak C., Dostosowanie prawa polskiego do instrumentów międzynarodowych dotyczacych korupcji, Raport Fundacji im. S. Batorego, Warszawa 2004.

Nowak C., Korupcja w polskim prawie karnym na tle uregulowań międzynarodowych, Warszawa 2008.

Parkitny S., Problem korupcyjnego charakteru prezentu w obrocie gospodarczym a odpowiedzialność karna, „Nowa Kodyfikacja Prawa Karnego” 2004, nr 15.

Potulski J., Glosa do postanowienia Sądu Najwyższego z dnia 30 września 2010 r., I KZP 16/10, „Gdańskie Studia Prawnicze - Przegląd Orzecznictwa” 2011, nr 2.

Potulski J., Komentarz do art. 115 kodeksu karnego, [w:] J. Potulski, Komentarz do ustawy z dnia 13 czerwca 2003 r. o zmianie ustawy - Kodeks karny oraz niektórych innych ustaw, Lex nr 74313.

Potulski J., Ruciński M., Odpowiedzialność sędziego sportowego za przyjęcie łapówki, „Prokuratura i Prawo” 2007, nr 9.

Raglewski J., Odpowiedzialność karna za korupcję gospodarcza (art. 296a k.k.), „Prawo Spółek” 2005, nr 6.

Rogalski M., Prawnokarna definicja funkcjonariusza publicznego oraz osoby petniacej funkcje publiczna w administracji samorzadowej, "Samorząd Terytorialny" 2005, nr 3.

Saloufakos-Parsons A., "Going for the Gold": an Application of the OECD Bribery Convention to the Olympic Games Scandals, "California Western International Law Journal" 2001, nr 31.

Shams H., The Fight Against Extraterritorial Corruption and the Use of Money Laundering Control, "Law and Business Review of the Americas” 2001, nr 7.

Sieńczyło-Chlabicz J., Prawo do ochrony sfery życia prywatnego osób publicznych $w$ świetle polskiej doktryny i orzecznictwa, "Przegląd Ustawodawstwa Gospodarczego" 2005, nr 2.

Skorupka J., Podstawy karania korupcji w kodeksie karnym de lege lata i de lege ferenda (wybrane zagadnienia), „Państwo i Prawo” 2003, nr 12.

Stefański R.A., Glosa do postanowienia Sąu Najwyższego z dnia 15 listopada 2002 r., IV KKN 570/99, „Orzecznictwo Sądów Polskich” 2003, z. 9, poz. 106.

Stefański R.A., Osoba petniąca funkcję publiczna jako podmiot przestępstwa łapownictwa, „Prokuratura i Prawo” 2000, nr 11. 
Stefański R.A., Przestępstwo korupcji w sporcie profesjonalnym (art. $296 b$ k.k.), „Prokuratura i Prawo" 2004, nr 2.

Sung H.-E., Between demand and supply: Bribery in international trade, "Crime, Law \& Social Change" 2005, nr 44.

Surkont M., Warunki odpowiedzialności lekarza za łapownictwo bierne, „Przegląd Sądowy" 2000, nr 11-12.

Szafraniec M., Przestępstwo łapownictwa w świetle ostatniej nowelizacji, „Palestra" 2004, nr 3-4.

Wąsek A. (red.), Komentarz do kodeksu karnego. Część szczególna, t. II, Warszawa 2004.

Węglowski M.G., Pojęcie "funkcji publicznej" w aspekcie przestępstwa łapownictwa, „Prokuratura i Prawo” 2003, nr 7-8.

Wolter W., Odpowiedzialność karna osób pełniacych funkcje publiczne, „Państwo i Prawo" 1969, nr 6.

Wyrembak J., Glosa do uchwały Sadu Najwyższego z dnia 30 kwietnia 2003 r., IKZP 12/13, „Państwo i Prawo” 2006, nr 11.

Zoll A. (red.), Kodeks karny. Część ogólna. Komentarz, t. I, Kraków 2004.

Zoll A. (red.), Komentarz do kodeksu karnego Część szczególna, t. 2, Kraków 1999.

\section{SUBJECT OF CORRUPTION OFFENCES \\ IN THE LIGHT OF INTERNATIONAL DOCUMENTS AND ACTS OF POLISH LAW}

\section{S u m m a r y}

Determination of persons capable of carrying criminal liability for acts of corruption is essential for understanding corruption in both sectors: public and private. The paper analyzed international anti-corruption documents adopted by global and regional international governmental organizations as well as polish law. The main object of the paper is to identify the definitions and scope of understanding of subjects of the corruption offences in the national public sector such us: "public officer" and "person who perform public function", as well as "foreign entities" operating in the international level and subject of the private sector.

Key words: public official, public function, foreign official, servant of international organizations, private sector, corruption, bribery 


\title{
СУБЪЕКТЫ КОРРУПЦИОННЫХ ПРЕСТУПЯЕНИЙ НА ОСНОВАНИИ МЕЖДУНАРОДНЫХ ДОКУМЕНТОВ И АКТОВ ПОЯЬСКОГО ПРАВА
}

\author{
P е 3 ro м e
}

Определение круга способных субъектов к несению уголовной ответственности за коррупционные поступки имеет ключевое значение для понимания коррупции в обоих секторах: публичным и частным. В исследовании было проанализировано документы касательно феномена коррупции, принятое под эгидой международных правительственных организаций о повсеместном и региональном характере, а также положения национального законодательства. Главным намерением было определение значностной сферы отдельных категорий национальных субъектов в публичном секторе, то есть: «публичного должностного иица» и «дица, выполняющую публичною функцию», также как «зарубежных субъектов», которые функционируют в международном измерении, все это дополняет для определения субъектов частного сектора.

Ключевые слова: публичное должностное лицо, публичная функция, зарубежный чиновник, должностное лицо международной организации, частный сектор, коррупция, взяточничество 